\title{
A New Species of Sipuncula (Aspidosiphon exiguus n.sp.), Belonging to the Interstitial Fauna of Marine Beaches Collected by Mr. L. Botosaneanu during the Second Cuban-Romanian Biospeleological Expedition to Cuba 1973
}

by

\section{S. J. EDMONDS*}

Aspidosiphon Diesing 1851 (in part); Stephen, 1965: 45; Stephen \& Edmonds, 1972: 216.

\section{LOCALITY, ETC.}

The following information is supplied by Dr. L. Botosaneanu (Institute of Speology, Bucharest) who collected the specimens during the second CubanRomanian Biospeleological Expedition to Cuba-1973 and kindly sent them to me for identification.

Localities: Playa Siboney (15.2.73), Playa Juragua (16.2.73) and Playa Baconao (24.3.73).

"These three localities are extremely similar. They are three beaches of the Caribbean See, located on the southern coast of the eastern extremity of the Island, at the foot of the Gran Piedra Mountain. The sand of these beaches is mainly of fluviatile origin but there are also many coral fragments in the sand. It is coarse, loose and clean (without much plant detritus). The samples were made by digging holes into the sand ("Karaman-Chappuis sondages") 1-3 m from the wave line and filtering through a net the water which more or less rapidly fills these holes. This water is strongly brackish, anyway less salt than the sea. The temperature of the water filling the holes was $28^{\circ} \mathrm{C}$ (Siboney), $21^{\circ}$ (Juragua) and $27^{\circ} \mathrm{C}$ (Baconas). The three beaches have very rich and varied interstitial fauna."

\section{DESCRIPTION}

The collection consisted of about 25-30 very small animals** (trunk usually about $3 \mathrm{~mm}$ long), whitish in colour and semi- to almost completely transparent to transmited light. No eggs were found in the body cavity of any of the specimens so

*) Department of Zoology, University of Adelaide, South Australia.

**) Some other specimens were not sent to me but remained in the collections of the Institute of Speology, Bucharest. 
that it is difficult to say whether they were adults. The body wall was so thin and the specimens so small that the animals were difficult to dissect. Fig. 1 was drawn from an undissected specimen.

Trunk more or less cylindrical with smooth skin; length 1-5-4.2 mm and width 0.4-0.9 mm. Anal (anterior) and caudal (posterior) shields pale yellow in colour and composed of small polygonal plates. Shields without furrows. In about eight specimens the caudal shield is poorly developed and appears to be rudimentary or even absent.

Introvert fine, in the fully extended condition up to $15 \mathrm{~mm}$ long and much longer than the trunk. It arises eccentrically from the trunk, ventral to the anal shield. Anteriorly it is armed with 20-24 rows of very small, clear, double-pointed hooks; at the base of each hook are a number of curved bars. Spines are absent though at least in four specimens a few, single pointed clear hooks, about the same size as the double pointed ones, were sparsely distributed posterior to the region which bears the rows of doubled pointed hooks. No spines are present on the posterior region of the introvert.

Papillae lie on the surface of the introvert. They consist of two parts, a hemispherical basal portion from which arises a small, narrow tubular portion. The size and shape of some of the papillae taken from the mid-region of the introvert are shown in Fig. 5. The papillae at the base of the introvert are slightly larger and

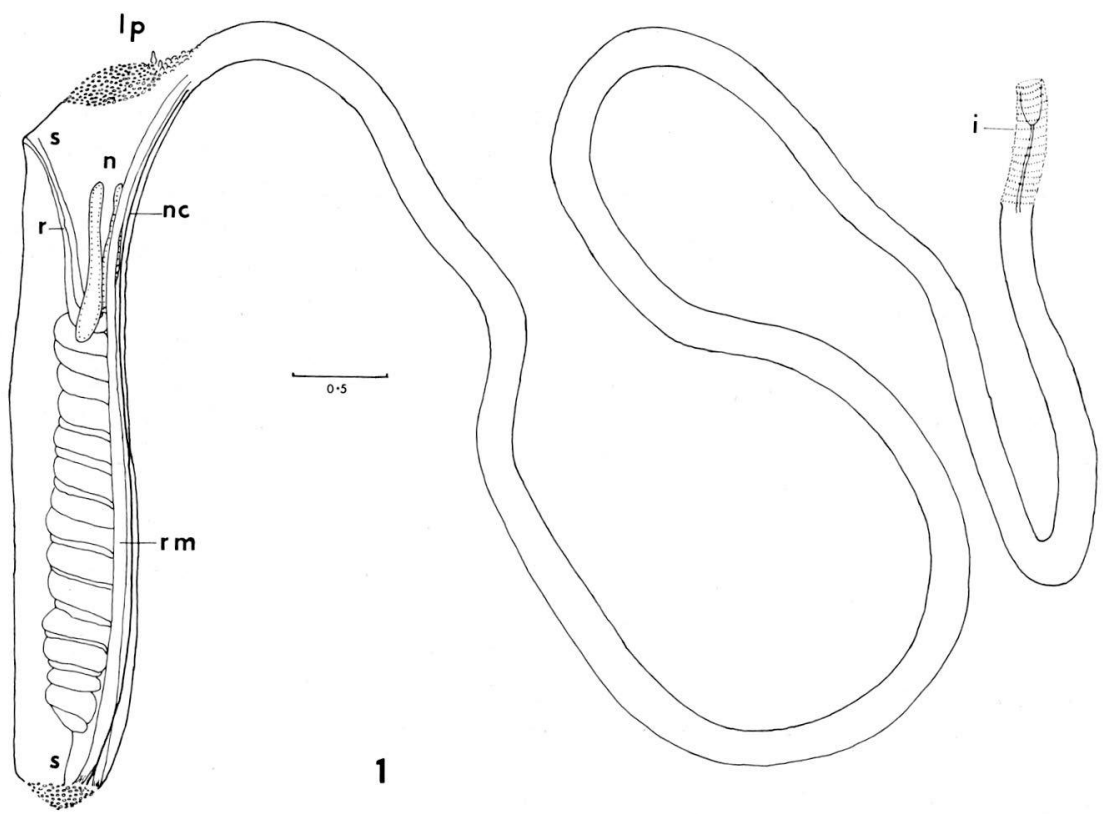

Fig. 1. Entire animal; $i=$ introvert hooks, $l p=$ large papillae, $n=$ nephridia, $n c=$ nerve cord, $r=$ rectum, $\mathrm{rm}=$ retractor muscle, $\mathrm{s}=$ spindle muscle. 


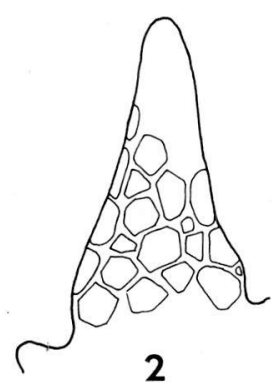

5

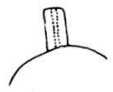

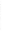

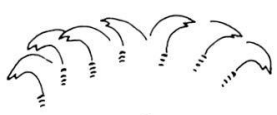

3

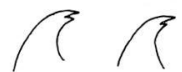

4

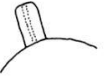

Figs. 2-7

2. Larger papilla from base of introvert. 3. Arrangement of introvert hooks. 4. twopointed hooks. 5. Papillae from introvert. 6. Papillae from trunk. 7. Single-pointed hooks (spines).

more variable in shape. On the dorsal surface of the trunk just anterior to the anal shield a number of larger hemispherical papillae are present. In most specimens a few become tall, prominent, more or less conical structures with rounded tips (Fig. 2). The surface of the trunk is smooth. It bears, however, numerous small, flat papillae comprised of a few small polygonal plates. No tentacles were observed in expanded or dissected specimens.

Longitudinal musculature continuous with no sign of banding. Retractor muscle single for most of its length but arising from two short roots which are fastened to or very near the caudal shield. Intestine coiled and anus often prominent. Rectum of variable size. No caecum observed. Contractile vessel poorly developed. Spindle muscle fastened anteriorly near the anus and posteriorly to or near the caudal shield.

Two nephridia arise at about the level of the anus or just posterior to it; their length is about a quarter or a third that of the trunk.

\section{SYSTEMATIC POSITION}

These specimens belong to the genus Aspidosiphon Stephen, 1965 and fall in the subgroup the members of which possess some introvert hooks with two points (Stephen \& Edmonds, 1972: 218).

A number of aspidosiphonids have been previously reported from Cuba. Murina (1967a and 1967b) reported (1) A. fischeri cubanus Murina, (2) A. spinososcutatus 
Fischer (1922), (3) A. steenstrupii Diesing, 1859, (4) A. brocki Augener, 1903, (5) $A$. albus Murina and (6) A. hartmeyeri Fischer, 1919. Of these species (1), (2) and (3) belong to the genus Paraspidosiphon in which the longitudinal musculature is grouped into bundles, a condition not noticed in any of my specimens.

Of the above mentioned species the present specimens resemble most closely $A$. albus Murina, 1967. A. albus, however, as described both by Murina (1967b) and Cutler (1973) lacks introvert hooks and spines. My specimens possess rows of clear or uncoloured hooks with two points and a few sparsely scattered hooks (or spines? ) with single points. The rows of hooks show up well even in specimens with a retracted introvert. Consequently they cannot be regarded as $A$. albus. I have compared them with some specimens of $A$. hartmeyeri collected near the type locality in Western Australia. A. hartmeyeri, though small (10-14 mm long), is a more robust species with shields that are dark and clearly furrowed. The posterior region of the introvert carries well developed spines which are lacking in these Cuban specimens. The specimens also differ from $A$. brocki, described from Indonesia, because (1) they lack the kind and number of introvert spines as shown for $A$. brocki in Augener's (1903) Fig. 11, (2) the introvert hooks are clear and lack the darker and lighter areas shown in Augener's Figs. 10 and 10a, (3) they possess 1-4 prominent elongated papillae just anterior to the anal shield, (4) their introvert is a much longer structure than that of $A$. brocki (5) they are significantly smaller (the trunk of $A$. brocki is as long as $40 \mathrm{~mm}$ ).

Some other species of Aspidosiphon have been described from the eastern coast of U.S.A. A. zinni Cutler, 1973 is also a very small, transparent species. Its hooks, however, are single-pointed and irregularly arranged, that is, not in rows. Its introvert, too, is swollen anteriorly. Cutler (1973) also reported A. spinalis Ikeda, 1904 from southern Florida. According to Ikeda the introvert is armed with dark brown spines that are sharply pointed, resembling a thin chitinous lamella folded into a funnel. These spines gradually become taller towards the base of the introvert. No such structures are present in the Cuban specimens. Wesenberg-Lund (1954) reported $A$. elegans from Florida. The Cuban specimens lack the red-yellow spines of $A$. elegans and the kind of papillae shown in Fig. 206 of Selenka (1883). The retractor of $A$. elegans join the body wall well in front of the caudal shield. The musculature of the body wall of $A$. parvulus Gerould, 1913 is grouped into bundles (Cutler 1973: 179).

For these reasons I am regarding these specimens as new. Type material. British Museum (Nat. Hist.), London. Additional specimens; Australian Museum, Sydney and Institute of Speology, Bucharest.

\section{DIAGNOSIS}

Small, almost transparent. Anal and caudal shields composed of very small, pale-yellow, polygonal plates without furrows. Introvert two to five times as long as trunk, armed anteriorly with about 20 rows of very small, clear, double-pointed hooks. A few small hooks (spines? ) with single points sparsely scattered over anterior half of 
introvert of some specimens; they are isolated structures and in some specimens are absent. Posterior half of introvert without hooks or spines. Commonest papillae on introvert consist of two parts, a basal hemispherical part from which arises a short tubular or cylindrical part. A few papillae on the trunk lying anterior to the shield are enlarged, elongate, cone-like structures. Their apex is blunt and not sharp. Caudal shield may be weakly developed or absent. Retractor muscle single for most of its length but stemming from two short roots, which are fastened to or very near the caudal shield. Nephridia about one-third as long as the trunk; nephridiopore on same level as or just posterior to that of the anus.

\section{RESUME}

Aspidosiphon exiguus, nouvelle espèce de Sipunculien de Cuba, appartenant à la faune interstitielle des rivages marins, recueillie au cours de la seconde expédition biospéléologique cubano-roumaine en 1973.

L'Auteur décrit Aspidosiphon exiguus, n. sp. d'après 25-30 spécimens de 1,5 à $4,2 \mathrm{~mm}$ de long et de 0,4 à $0,9 \mathrm{~mm}$ de large, récoltés dans 3 localités de la côte sud de l'extrémité orientale de Cuba. Cette espèce est bien distincte des autres formes décrites ou signalées de Cuba et de la côte est des Etats Unis par sa taille, sa musculature pariétale longitudinale, la forme, le nombre et la disposition des crochets et épines de son introvert. Ce dernier critère permet de la distinguer de $A$. albus Murina qui en est très proche, mais qui est dépourvue de ces phanères.

\section{REFERENCES}

AUGENER, H. 1903. Beiträge zur Kenntnis der Gephyreen nach Untersuchung der im Göttinger zoologischen Museum befindlichen Sipunculiden und Echiuriden. Arch. Naturgesch. 69: 297-371, pls. 16-20.

CUTLER, E. B. 1973. Sipuncula of the Western North Antarctic. Bull. Am. Mus. Nat. Hist. 152 (3): 103-204, 59 figs. 13 tables.

IKEDA, I. 1904. The gephyrea of Japan. J. Coll. Sci. imp. Univ. Tokyo 20 (4): 1-87, 4 pls.

MURINA, V. V. 1967a. On the sipunculid fauna of the littoral zone of Cuba. Zool. Zh. 46: 35-46, 8 figs.

1967b. Report on the sipunculid fauna of the sublittoral zone of Cuba and the Mexican Gulf. Zool. Zh. 46: 1329-1339. 6 figs.

SELENKA, E., DE MAN, J. G. and BUELOW, C. 1883. Die Sipunculiden. Reisen im Archipel Philippinen von Dr. C. Semper. Leipzig; pt. 2 (4): 1-133, 14 pls.

STEPHEN, A. C. 1965. A revision of the phylum Sipuncula. Ann. Mag. Nat. Hist. ser. 13, 7: 457-462.

STEPHEN, A. C. \& EDMONDS, S. J. 1972. The phyla Sipuncula and Echiura. Trustees Brit. Mus (Nat. Hist.) Pub. No. 717.528 pp. 60 figs.

WESENBERG-LUND, E. 1954. Priapuloidea, Sipunculoidea and Echiuroidea. Bull. Inst. r. Sci. nat. Belg. 30 (16): 1-18, 1 pl., 3 text figs. 